\section{Incidental findings and patient autonomy}

In their article on handling incidental findings, Ells and Thombs ${ }^{1}$ compare the extensive official guidance available in the United States with the rather more concise comments for Canadian researchers in the Tri-Council Policy Statement. ${ }^{2}$ Although the report, "Anticipate and communicate: ethical management of incidental and secondary findings in clinical, research, and direct-to-consumer contexts," 3 provides helpful details for US-based research, the Tri-Council Policy Statement is essential in the Canadian context.

A core principle of the statement is respect for persons, which incorporates the dual moral obligations to "respect autonomy and protect those with developing, impaired or diminished autonomy." ${ }^{2}$ In the case of the competent patient, the moral obligation, according to article 1.1, is to respect autonomy. The statement further clarifies that "[r]especting autonomy means giving due deference to a person's judgment and ensuring that the person is free to choose without interference." Dictating what incidental information is withheld, in the absence of patient input, interferes with a patient's freedom to choose without interference.

Ells and Thombs' ${ }^{1}$ recommendation that the plans for incidental findings simply be described to patients could be revised to ensure patient awareness of their own autonomy. Article 1.1 could be preserved by seeking the patient's decision after describing the potential benefits and harms of disclosure of the incidental findings. This approach could elicit an informed decision while respecting patient autonomy and values and could be applied even when patient preferences differ from current research on the benefits and harms of disclosure. ${ }^{4}$

\section{Sean M. Nurmsoo MSc}

Researcher, Dalhousie University, Halifax, NS

\section{References}

1. Ells C, Thombs BD. The ethics of how to manage incidental findings. CMAJ 2014;186:655-6.

2. Tri-Council Policy Statement: ethical conduct for research involving humans. Ottawa (ON): Canadian Institutes of Health Research, Natural Sciences and Engineering Research Council of Canada, Social Sciences and Humanities Research Council of Canada; 2010. Available: www.pre.ethics .gc.ca/eng/policy-politique/initiatives/tcps2-eptc2 /Default/ (accessed 2014 June 23).

3. Anticipate and communicate: ethical management of incidental and secondary findings in clinical, research, and direct-to-consumer contexts. Washington (DC): Presidential Commission for the Study of Bioethical Issues; 2013. Available: http://bioethics.gov/node/3183 (accessed 2014 Jun. 23).

4. Montori VM, Brito JP, Murad MH. The optimal practice of evidence-based medicine: incorporating patient preferences in practice guidelines. JAMA 2013:310:2503-4.

CMAJ 2014. DOI:10.1503/cmaj.114-0063

\section{Suicidal ideation and poverty in First Nations}

Eggertson's article on gas sniffing shines a light on the conditions on the Pikangikum First Nation in Ontario. ${ }^{1}$

From 2007 to 2008, 25 of Pikangikum's 2500 residents ( $1 \%$ of the population) took their own lives; 16 were children under the age of $19 .^{2}$ This would be comparable to about 28000 Torontonians taking their own lives. The number of suicides in Ontario each year is about $1100 .^{2}$

As the Ontario Coroner's Report outlines, Pikangikum has inadequate, overcrowded housing, no indoor plumbing, little gainful employment, continuous food and water insecurity and no connectivity to the hydro grid. In 2007, 542 heads of household received social assistance. ${ }^{3}$ This poverty results in substance abuse: children sniff gasoline, adults abuse alcohol. Death due to suicide is pervasive.

Canada continues to accept poverty as a societal inevitability. Yet the poverty rates of other wealthy nations (i.e., Sweden) are less than half of Canada's. ${ }^{4}$ Canada ranks 21 st in the world in child poverty, and 22 nd in infant mortality. ${ }^{5}$ Can we justify excess infant mortality and youth suicides in First Nations based on policy choices?

We need to establish a guaranteed annual income for all impoverished
Canadians, including First Nations citizens. Our per capita spending on health care would likely decrease and population health would likely increase. Nordic nations, such as Sweden are "social democratic political economies" that "promote economic and social security for their citizens."

Poverty is associated with poorer health for every income quintile. ${ }^{7}$ Canada should redistribute its wealth to improve health, living standards and well-being for our vulnerable populations. We have been late to accept the concept of the social determinants of health. If we address poverty among First Nations people, we will likely begin to see mental illness, substance abuse and suicide rates abate in communities like Pikangikum.

\section{Bert Lauwers MD}

Vice President - Medical and Chief of Staff, Ross Memorial Hospital, Lindsay, Ont.

\section{References}

1. Eggertson L. Children as young as six sniffing gas in Pikangikum. CMAJ 2014;186:171-2.

2. The Office of the Chief Coroner's death review of the youth suicides at the Pikangikum First Nation 2006-2008. Toronto: Office of the Chief Coroner; 2011: 50.

3. The North South Partnership for Children and the Pikangikum Community Members participatory assessment of Pikangikum. Toronto: North South Partnership for Children; 2008:12.

4. Rachlis M, Goel R, Mackie C, et al. Policy and population approaches to poverty. Ont Med Rev 2013; 80:30.

5. Adamson P. Child well-being in rich countries: comparative overview: Innocenti Report Card 11 UNICEF; 2013:7

6. Raphael D, editor. Health promotion and quality of life in Canada: essential readings. Toronto: Canadian Scholar's Press; 2010:282.

7. Dorman K, Pellizzari R, Rachlis M, et al. Why poverty is medical problem. Ont Med Rev 2013;80:17.

CMAJ 2014. DOI:10.1503/cmaj.114-0065

\section{Perspectives on studying abroad}

Barer and colleagues ${ }^{1}$ present a sobering picture for Canadians studying abroad. Although the number of Canadians studying abroad continues to grow, the demographics of this population are changing. Personally, I have seen a decrease in the age of those applying to international medical schools and an 